\title{
PEMBUATAN DAN UJI ORGANOLEPTIK SEDIAAN SERBUK INSTAN DAUN KATUK ( Sauropus androgynus-(L) Merr) DAN TEMULAWAK (Curcuma xanthorrhiza Roxb)
}

\author{
Gunawan Muhammad1', Agus Djamaluddin'*, Farhan ${ }^{3}$ \\ ${ }^{1}$ Sekolah Tinggi Ilmu Kesehatan Holistik \\ *Korespondensi: Jl. Veteran No.272 Ciseureuh Purwakarta, Email: djamaludina@gmail.com
}

\begin{abstract}
ABSTRAK
Latar Belakang: Air Susu Ibu (ASI) merupakan makanan sumber protein yang baik untuk bayi namun beberapa ibu menyusui pengeluaran ASI terlambat sehingga tidak lancar. Diketahui secara empiris daun katuk dan temulawak dapat meningkatkan produksi ASI. Maka dibuatlah sediaan serbuk instan dari daun katuk dan temulawak.

Tujuan Penelitian: Membuat dan menentukan formulasi sediaan serbuk instan dari daun katuk dan temulawak yang dilakukan dengan cara uji organoleptik.

Metode: Penelitian tindakan berupa perlakuan tunggal disusun dalam Rancangan Acak Lengkap (RAL) dengan 2 perlakuan dan 5 ulangan. Perlakuan tunggal adalah dosis gula yang terdiri dari 4 taraf yaitu G1 = penambahan gula 150 gram/liter, G2 = penambahan gula 200 gram/liter, G3 = penambahan 250 gram/liter, dan G4 = penambahan gula 300 gram/liter.

Hasil: Dalam pengujian organoleptik semua sediaan dapat bertahan selama tiga minggu kemudian dari ke empat sampel terdapat perbedaan yang signifikan sampel G1, G2, G3, G4 pada segi warna, rasa, serta jumlah yang di hasilkan pada saat pembuatan.

Simpulan: Penambahan gula pada setiap sampel mempengaruhi bentuk sediaan berupa warna yang berbeda rasa yang berbeda serta jumlah sediaan yang di hasilkan tiap sampel juga berbeda.
\end{abstract}

Kata kunci: daun katuk, temulawak, sediaan instan, serbuk instan

\begin{abstract}
Background: Breast milk (ASI) is a good source of protein for babies, but some mothers breastfeed late breast milk so it is not smooth. Empirically known katuk leaves and temulawak can increase milk production. So an instant powder preparation was made from katuk and temulawak leaves.

objective: Make and determine the formulation of the preparation of instant powder from katuk and temulawak leaves which is done by organoleptic test.

Method: Action research in the form of a single treatment was arranged in a Completely Randomized Design (CRD) with 2 treatments and 5 replications. Single treatment is a dose of sugar consisting of 4 levels, namely G1 = addition of sugar 150 grams / liter, G2 = addition of sugar 200 grams / liter, G3 = addition of 250 grams /liter, and G4 = addition of sugar 300 grams / liter.

Results: The addition of sugar in each sample affected the dosage form in different colors and the number of preparations produced in each sample was also different.

Conclusion: Addition of sugar in each sample affects the dosage form in different colors of different flavors and the number of preparations produced by each sample is also different.

Keywords: katuk leaves, Temulawak, instant preparations, instant powder
\end{abstract}

\section{PENDAHULUAN}

Daun katuk secara tradisional telah digunakan oleh masyarakat khususnya ibuibu untuk meningkatkan produksi Air Susu Ibu (ASI). ${ }^{1}$ Selain untuk memperlancar produksi ASI, daun katuk juga digunakan sebagai obat tradisional untuk mengobati sakit padakerongkongan. Pemberian ekstrak daun katuk pada kelompok ibu melahirkan dan menyusui bayinya dengan dosis 3 x $300 \mathrm{mg} /$ hari selama 15 hari terus menerus mulai hari ke-2 atau hari ke-3 setelah melahirkan dapat meningkatkan produksi ASI 50,7\% lebih banyak dibandingkan dengan kelompok ibu melahirkan dan menyusui bayinya yang tidak diberi ekstrak daun katuk. ${ }^{1}$

Selain daun katuk, tanaman obat lainya yang mempunyai khasiat obat yaitu temulawak. Temulawak merupakan 
tanaman herbal yang khasiatnya salah satunya untuk menambah nafsu makan. Ramuan herbal sudah dipergunakan secara turun temurun karena selain bernilai ekonomis juga efek samping sangat kecil. Penggunaan obat herbal alami dengan formulasi yang tepat sangat penting dan tentunya lebih aman juga efektif. ${ }^{2}$

Berdasarkan hal tersebut penelitian ini bertujuan membuat sediaan yang berbahan dasar daun katuk dan temulawak ditambah gula yang di buat menjadi serbuk instan kemudian diuji tingkat stabilitas dari sediaan.

\section{METODE PENELITIAN}

Penelitian ini menggunakan metode penelitian tindakan dan teknik pengumpulan data menggunakan observasi kualitatif. Penelitian tindakan (action reseach) merupakan upaya menguji cobakan ide-ide ke dalam praktek untuk memperbaiki atau mengubah sesuatu agar memperoleh dampak nyata dari situasi. ${ }^{3}$ Dalam penelitian kualitatif, pengumpulan data dilakukan pada natural setting (kondisi yang alamiah), sumber data primer dan teknik pengumpulan data lebih banyak pada observasi dan dokumentasi. ${ }^{4}$ Observasional yaitu suatu prosedur yang berencana, yang antara lain meliputi melihat, mendengar, dan mencatat sejumlah dan taraf aktivitas tertentu atau situasi tertentu yang ada hubungannya dengan masalah yang diteliti..$^{5}$ Penelitian dilakukan dengan menambahkan dosis gula yang bervariasi. Dosis gula yang terdiri dari 4 taraf yaitu G1 = penambahan gula 150 gram/liter, G2 = penambahan gula 200 gram/liter, G3 = penambahan 250 gram/liter, dan G4 = penambahan gula 300 gram/liter.

Pembuatan serbuk intan mengacu pada standar resep serbuk instan yang diperoleh dari trial and error dari sejumlah penelitian yang mengacu pada standar resep serbuk intan dengan beberapa modifikasi. Adapun lama pembuatan sediaan instan 150 menit yaitu maserasi 30 menit penggodogan 30 menit pengadukan dengan api kecil hingga sediaan jadi 90 menit.

Tabel 1. Formulasi sediaan serbuk instan

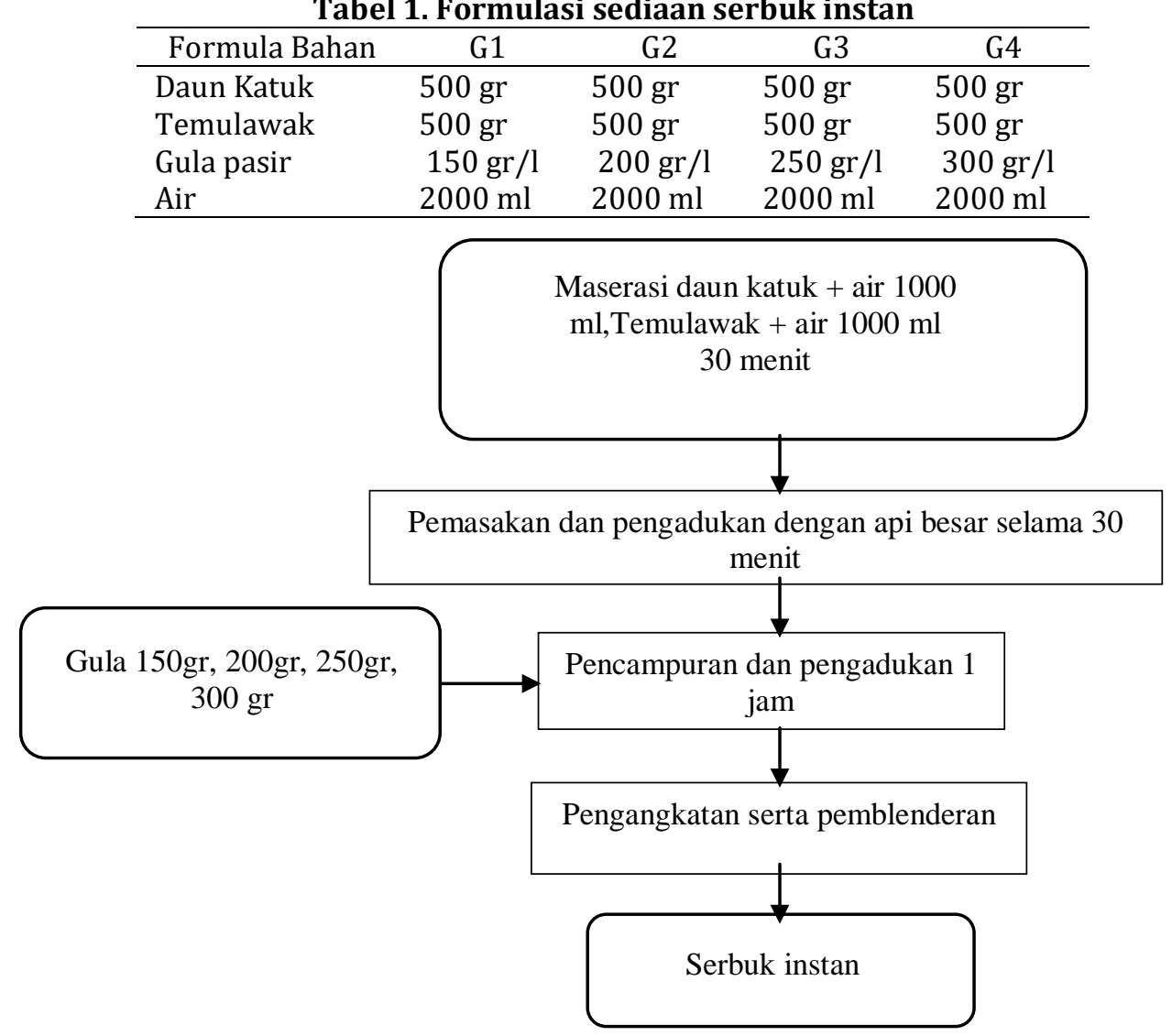

Gambar 1. Diagram Alir Pembuatan Serbuk instan 
Penelitian dilakukan dengan air. pengamatan fisik Organoleptik (warna, bau, rasa, bentuk) yang dilakukan selama tiga minggu., dengan 4 konsentrasi gula yang berbeda disimpan pada suhu ruangan yaitu 20-250 C sedang pengujian kelarutan dilakukan dengan cara melarutkan sediaan sebanyak 1 gram kedalam 2 - 1000 bagian

Data hasil penelitian di analisis menggunakan Teknik observasi kualitatif yaitu pencatatan serta dokumentasi selama pengujian hingga akhir pengujian.

\section{HASIL PENELITIAN}

Tabel 2. Hasil Analisis Uji organoleptik

\begin{tabular}{|c|c|c|c|c|}
\hline Perlakuan & Warna & Bau & Rasa & Berat \\
\hline G1 (Gula 150gr/l) & Hijau tua aga hitam & $\begin{array}{l}\text { Khas daun katuk dan } \\
\text { temulawak }\end{array}$ & Manis pahit & $205 \mathrm{gr}$ \\
\hline G2 (Gula 200gr/l) & Hijau tua & $\begin{array}{l}\text { Khas daun katuk dan } \\
\text { temulawak }\end{array}$ & Manis agak pahit & $220 \mathrm{gr}$ \\
\hline G3 (Gula 250gr/l) & Hijau agak kekuningan & $\begin{array}{l}\text { Khas daun katuk dan } \\
\text { temulawak }\end{array}$ & Manis sedang & $280 \mathrm{gr}$ \\
\hline G4 (Gula 300gr/l) & $\begin{array}{l}\text { Hijau muda agak } \\
\text { keputihan }\end{array}$ & $\begin{array}{c}\text { Khas daun katuk dan } \\
\text { temulawak }\end{array}$ & Manis & $360 \mathrm{gr}$ \\
\hline
\end{tabular}

Berdasarkan uraian Tabel 2, terdapat perbedaan nyata antara sediaan serbuk instan G1 dengan tiga perlakuan lainnya, dari segi warna, bau, rasa, dan berat yang dihasilkan berbeda. Dari hasil analisis tersebut dapat disimpulkan bahwa jumlah gula yang di berikan berpengaruh terhadap sediaan semakin banyak gula yang di pakai semakin banyak pula serbuk yang di hasilkan serta semakin banyak gula semakin manis pula sediaan yang dihasilkan.

Tabel 3. Hasil Analisis uji kelarutan serbuk instan

\begin{tabular}{ccccc}
\hline \multirow{2}{*}{ Perlakuan } & \multicolumn{4}{c}{ Tingkat kelarutan } \\
\cline { 2 - 5 } & $\begin{array}{c}\text { Sangat larut } \\
\text { Kurang dari 1 } \\
\text { bagian air }\end{array}$ & $\begin{array}{c}\text { Mudah larut } \\
\text { 1-10 bagian }\end{array}$ & $\begin{array}{c}\text { Larut } \\
\text { 10-30 bagian }\end{array}$ & $\begin{array}{c}\text { Agak sukar } \\
\text { larut 30- 100 } \\
\text { bagian air }\end{array}$ \\
\hline G1 & & $\checkmark$ & air & bar \\
G2 & $\checkmark$ & & \\
G3 & $\checkmark$ & & \\
G4 & & $\checkmark$ & & \\
\hline
\end{tabular}

Hasil uraian Tabel 3 menunjukkan bahwa semua sediaan larut pada 1-10 bagian air hal ini menunjukan bahwa tidak terdapat perbedaan atau pengaruh dari gula terhadap jumlah kelarutan yang di hasilkan.

\section{PEMBAHASAN}

Daun katuk yang digunakan dalam penelitian ini diperoleh dari daerah Kalijati Subang. Daun katuk yang dipetik merupakan daun yang berwarna hijau tua dan muda. Daun katuk yang telah dipetik dibersihkan dengan cara mencuci dengan air mengalir,daun katuk ditiriskan kedalam wadah yang berlubang/ayakan hal ini dimaksudkan agar daun katuk bebas dari air. Bahan kedua merupakan temulawak yang kemudian diperlakuan sama seperti daun katuk.

Pembuatan sediaan serbuk intan dilakukan dengan cara maserasi daun katuk dan temulawak kedalam $1000 \mathrm{ml}$ air selama 30 menit kemudian hasil maserasi di masukan ke wajan untuk proses pemasakan dan pengadukan selama 30 menit, setelah pemasakan selama 30 menit atau sampai sediaan terlihat kental dalam wajan tambahkan gula kemudian terus aduk sediaan pada api sedang sampai sediaan menjadi serbuk kering. Setelah itu masukan sedian kedalam blender agar serbuk terlihat lebih halus. Lakukan proses pembuatan untuk gula dengan porsi yang berbeda. 
Pengujian organoleptik sediaan selama 3 minggu dilakukan dengan cara mengamati sediaan pada suhu ruangan yaitu $20-25^{\circ} \mathrm{C}$ dengan tujuan untuk menguji kestabilan sediaan dan memastikan tidak terjadinya perubahan bentuk, warna, bau, rasa, maupun tumbuhnya jamur didalamnya. Hasil yang didapat selama tiga minggu menunjukan bahwa tidak adanya perubahan dalam hal bentuk, bau, rasa, warna, maupun tumbuhnya jamur pada sediaan tersebut dikarenakan pada tahapan dalam penyiapan bahan serta pembuatan sudah sesuai dengan litelatur yang digunakan yaitu jurnal, sehingga dapat dikatakan bahwa sediaan yang peneliti buat tahan selama tiga minggu. Pengujian organoleptik setelah 3 minggu pun dilakukan untuk memastikan bahwa sediaan yang dibuat lulus uji ketahanan sediaan lebih dari tiga minggu. Dari ke empat formulasi, formulasi G3 dijadikan hasil akhir karena sediaan ini memiliki rasa yang pas yaitu tidak terlalu manis dan terlalu pahit sehingga cocok untuk di komsumsi oleh masyarakat.

Penelitian ini merupakan suatu penelitian pengembangan yang berupa pembuatan sediaan serbuk instan dari bahan herbal yang diperuntukan untuk menambah produksi asi pada ibu menyusui serta menambah nafsu makan. Bahan herbal yang digunakan yaitu daun katuk dan temulawak yang dibuat kedalam bentuk sediaan serbuk instan yang dapat diminum dengan cara diseduh yang penggunaannya sangat praktis. Penelitian ini hanya sebatas melakukan pengujian organoleptis terhadap sediaan yang telah dibuat, meliputi pengamatan terhadap bentuk, rasa, warna, bau, serta tumbuhnya jamur pada sediaan yang dilakukan selama tiga minggu.

\section{SIMPULAN}

Dari hasil pengujian organoleptik dihasilkan 4 sediaan dengan rasa yang sedikit berbeda salah satunya mempunyai rasa yang pas yaitu rasanya tidak terlalu manis serta tidak terlalu pahit sediaan ini dapat bertahan selama tiga minggu dengan keadaan fisik yang relatif tidak berubah. Sediaan serbuk instan ini dibuat untuk melancarkan produsi asi pada ibu menyusui dengan konsentrasi daun katuk $500 \mathrm{gr}$, temulawak 500gr, gula putih 250gram/liter. Dalam penelitian ini semua sampel larut dalam 2 bagian air. Untuk penelitian lanjutan dapat dilakukan lebih lanjut tentang khasiat dari sediaan yang dibuat karna keterbatasan alat serta waktu yang dibutuhkan cukup lama untuk meneliti sebuah sediaan.

\section{DAFTAR PUSTAKA}

1. Sa'roni, S. R., Sadjiman, T., Sja'bani, M., \& Zulaela, Z. (2004). Effectiveness Of The Sauropus Androgynus (L.) Merr Leaf Extract In Increasing Mother's Breast Milk Production. Media Penelitian dan Pengembangan Kesehatan, 14(3 Sept).

2. Agromedia. 2008. Buku Pintar Tanaman Obat, 431 Jenis Tanaman Penggempur Aneka Penyakit. Jakarta: PT. Agromedia Pustaka

3. Kemmis, S. \& McTaggart, R. 1988. The Action Research Planner. Third Edition.Victoria: Deakin University Press.

4. Sugiyono.2012. Memahami penelitian kualitatif. Alfabeta. Bandung

5. Notoatmodjo S. 2012. Promosi Kesehatan dan Perilaku Kesehatan. Jakarta: PT Rineka Cipta 